University of Nebraska - Lincoln

DigitalCommons@University of Nebraska - Lincoln

\title{
Spring home ranges of white bass in irrigation reservoirs of the Republican River Basin, Nebraska
}

D. R. Martin

University of Nebraska-Lincoln, dustin.martin@huskers.unl.edu

Larkin A. Powell

University of Nebraska-Lincoln, Ipowell3@unl.edu

Kevin L. Pope

University of Nebraska - Lincoln, kpope2@unl.edu

Follow this and additional works at: https://digitalcommons.unl.edu/natrespapers

Part of the Natural Resources and Conservation Commons

Martin, D. R.; Powell, Larkin A.; and Pope, Kevin L., "Spring home ranges of white bass in irrigation reservoirs of the Republican River Basin, Nebraska" (2009). Papers in Natural Resources. 179.

https://digitalcommons.unl.edu/natrespapers/179

This Article is brought to you for free and open access by the Natural Resources, School of at DigitalCommons@University of Nebraska - Lincoln. It has been accepted for inclusion in Papers in Natural Resources by an authorized administrator of DigitalCommons@University of Nebraska - Lincoln. 


\section{Letter}

\section{Spring home ranges of white bass in irrigation reservoirs of the Republican River Basin, Nebraska}

Martin DR, Powell LA, Pope KL. Spring home ranges of white bass in irrigation reservoirs of the Republican River Basin, Nebraska Ecology of Freshwater Fish 2009: 18: 514-519. (C) 2009 John Wiley \& Sons $\mathrm{A} / \mathrm{S}$

Abstract - Fishery biologists have documented small home ranges, relative to available habitat, for many littoral freshwater fishes. Home ranges for pelagic species, such as white bass Morone chrysops, are generally not well described, yet are thought to be large. We studied white bass movement using acoustic telemetry in two irrigation reservoirs of the Republican River basin in south-western Nebraska. Acoustic transmitters were implanted in fall of the previous year and tracking occurred a minimum of once per week throughout spring (mid-March to May) 2007 and 2008. Linear home ranges were calculated from observed locations of individual fish. Twelve of the twenty-seven tagged fish with at least five locations exhibited localised home ranges throughout the spring whereas the remaining fish exhibited home ranges extending across large portions of each reservoir. Home range size was not correlated with fish size or condition.

\author{
D. R. Martin', L. A. Powell', \\ K. L. Pope ${ }^{3}$
}

${ }^{1}$ Nebraska Cooperative Fish and Wildlife Research Unit, School of Natural Resources, University of Nebraska-Lincoln, Lincoln, NE, USA, ${ }^{2}$ School of Natural Resources, University of Nebraska-Lincoln, Lincoln, NE, USA,

${ }^{3}$ USGS-Nebraska Cooperative Fish and Wildlife Research Unit, School of Natural Resources, University of Nebraska-Lincoln, Lincoln, NE, USA

Key words: home range; white bass; acoustic telemetry

D. R. Martin, 118 Hardin Hall, Nebraska Cooperative Fish and Wildlife Research Unit, School of Natural Resources, University of NebraskaLincoln, Lincoln, NE 68583, USA; e-mail: dustin.martin@huskers.unl.edu

Accepted for publication July 3, 2009

\section{Introduction}

Home range is defined as the area that an individual travels through and uses for daily activities during a given period (Burt 1943). Home ranges have been described for many freshwater fish species including bluegill Lepomis macrochirus (Paukert et al. 2004), largemouth bass Micropterus salmoides (Winter 1977), flathead catfish Pylodictis olivaris (Weller \& Winter 2001; Vokoun 2003) and walleye Sander vitreus (Foust \& Haynes 2007). However, most home ranges previously estimated are for littoral-zone species that spend large amounts of time along the shoreline of a water body. Movements defining a home range are specific to individuals and differ from population-directed movements such as seasonal and spawning migrations. Within a single population, some fish may have restricted movements and localised home ranges whereas other fish may have large home ranges (Gerking 1959). However, the source of this variation among individual home-range sizes is often unknown.

Pelagic freshwater fishes, such as striped bass Morone saxatilis and white bass M. chrysops, are often highly mobile and may roam an entire water body in search of food and other necessary resources. The striped bass has strong site fidelity and localised home ranges in both estuary and reservoir systems (Jackson \& Hightower 2001; Ng et al. 2007). Summer home ranges of the striped bass are often limited in southern reservoirs because of low dissolved oxygen and hot water temperatures (Jackson \& Hightower 2001). Though no information exists on home ranges of white bass, white bass movements have been assessed in prior studies. Individual white bass move up to $11.1 \mathrm{~km} \cdot$ day $^{-1}$ in search of food (Scott \& Crossman 1973). Beck \& Willis (2000) used biotelemetry to determine that white bass were usually located nearshore during spring and autumn months and offshore during winter and summer months in a South Dakota glacial lake. Multiple regression models quantifying distance of white bass locations from the nearest shore were weakly affected by temperature, cloud cover, precipitation and moon phase (all $R^{2}<0.26$; Beck \& Willis 2000). Our objective was to quantify spring home ranges of white bass in two reservoirs within the Republican River basin of south-western Nebraska. 


\section{Study area}

Enders Reservoir is an irrigation reservoir constructed along Frenchmen Creek, in Chase County, Nebraska, by the U.S. Bureau of Reclamation in 1951. At conservation pool, Enders Reservoir has a water level of $948.5 \mathrm{~m}$ above mean sea level, surface area of $485 \mathrm{ha}$ and maximum depth of $18.3 \mathrm{~m}$. The shoreline is mostly composed of a silt/sand substrate with small cottonwood Populus deltoides trees lining the shoreline.

Hugh Butler Lake (Red Willow) is an irrigation reservoir constructed along Red Willow Creek in Frontier County, Nebraska, by the U.S. Bureau of Reclamation in 1962. At conservation pool, Hugh Butler Lake has a water level of $786.9 \mathrm{~m}$ above mean sea level, surface area of 660 ha and maximum depth of $15.2 \mathrm{~m}$. Hugh Butler Lake has two inflow sources creating a reservoir with two arms: Spring Creek to the north and Red Willow Creek to the west. The shoreline is mostly composed of a silt substrate with small cottonwood trees lining the shoreline.

\section{Materials and methods}

Thirty adult white bass (15 in Enders Reservoir and 15 in Hugh Butler Lake) were implanted using techniques described by Hart \& Summerfelt (1975) with Sonotronics ultrasonic tags (model IBT-96-9-1; $42 \mathrm{~mm}$ long, $10.5 \mathrm{~mm}$ diameter, $3.9 \mathrm{~g}$ weight in water) during autumn 2006; an additional 30 white bass (15 in each reservoir) were implanted during autumn 2007 (total tagged fish $N=60$ ). Tag weight was $<2.0 \%$ body weight and had a battery life expectancy of 9 months as reported by the manufacturer. Mean \pm standard error (SE) total length for all fish used in further analysis was $306 \pm 5 \mathrm{~mm}$, mean weight $\pm \mathrm{SE}$ was $350 \pm 22 \mathrm{~g}$ and mean $\pm \mathrm{SE}$ condition [relative weight $\left(W_{\mathrm{r}}\right)$; Wege \& Anderson 1978; Brown \& Murphy 1991] was $86 \pm 2$ at the time of tagging (Table 1).

Attempts to locate tagged white bass were made once a week during spring 2007 (17 attempts) and twice a week during spring 2008 (33 attempts). A typical sampling attempt consisted of a period of $12 \mathrm{~h}$ with days split into morning (03:00-15:00 h) and evening (15:00-03:00 h) sessions. Tracking attempts began after ice-out on 22 March 2007 and 5 March 2008 and ended on 29 May 2007 and 2 June 2008 due to loss of tag battery life. During each sampling event, we systematically worked around the reservoir stopping approximately every $300 \mathrm{~m}$ to scan (i.e. cycling through all frequencies with the directional hydrophone pointed at $0^{\circ}, 60^{\circ}, 120^{\circ}, 180^{\circ}, 240^{\circ}, 300^{\circ}$ and $360^{\circ}$ ) for tags. Once a tag was detected, we maintained a constant frequency while moving the boat to pinpoint the location of the fish. After pinpointing a fish's location, we resumed the systematic search. At least three circuits of the reservoir were completed
Table 1. Size and condition of fish (measured during tag implantation during September of previous year), number of spring (mid-March to May) locations and size of linear home ranges for white bass with greater than five locations at Enders and Hugh Butler Lakes, Nebraska, during 2007 and 2008. Condition was assessed using relative weight (Brown \& Murphy 1991; Wege \& Anderson 1978).

\begin{tabular}{|c|c|c|c|c|c|c|c|}
\hline Year & Reservoir & $\begin{array}{l}\text { Fish } \\
\text { number }\end{array}$ & $\begin{array}{l}\text { Total } \\
\text { length (mm) }\end{array}$ & $\begin{array}{l}\text { Weight } \\
\text { (g) }\end{array}$ & $\begin{array}{l}\text { Relative } \\
\text { weight }\end{array}$ & $\begin{array}{l}\text { Number of } \\
\text { locations }\end{array}$ & $\begin{array}{l}\text { Home } \\
\text { range }(m)\end{array}$ \\
\hline \multirow{12}{*}{2007} & \multirow[t]{9}{*}{ Enders } & 44 & 331 & 439 & 88 & 5 & 1725 \\
\hline & & 47 & 342 & 505 & 92 & 11 & 1186 \\
\hline & & 51 & 315 & & & 5 & 86 \\
\hline & & 53 & 306 & 360 & 92 & 7 & 3825 \\
\hline & & 58 & 321 & 409 & 90 & 6 & 1809 \\
\hline & & 64 & 259 & 239 & 102 & 6 & 2460 \\
\hline & & 67 & 325 & 436 & 93 & 10 & 1460 \\
\hline & & 68 & 269 & 253 & 96 & 9 & 1401 \\
\hline & & 71 & 331 & 458 & 92 & 5 & 2560 \\
\hline & \multirow[t]{3}{*}{ Hugh Butler } & 19 & 295 & & & 5 & 632 \\
\hline & & 38 & 314 & 320 & 76 & 5 & 1345 \\
\hline & & 39 & 300 & 275 & 75 & 6 & 239 \\
\hline \multirow[t]{15}{*}{2008} & \multirow[t]{7}{*}{ Enders } & 115 & 334 & 434 & 85 & 23 & 397 \\
\hline & & 125 & 309 & 371 & 92 & 14 & 2472 \\
\hline & & 129 & 300 & 357 & 97 & 14 & 231 \\
\hline & & 140 & 341 & 480 & 88 & 25 & 343 \\
\hline & & 157 & 349 & 526 & 90 & 14 & 168 \\
\hline & & 166 & 351 & 568 & 95 & 8 & 239 \\
\hline & & 171 & 306 & 357 & 91 & 6 & 3312 \\
\hline & \multirow[t]{8}{*}{ Hugh Butler } & 101 & 262 & 200 & 82 & 17 & 838 \\
\hline & & 107 & 316 & 343 & 79 & 12 & 8154 \\
\hline & & 116 & 310 & 311 & 76 & 15 & 298 \\
\hline & & 122 & 297 & 230 & 64 & 14 & 605 \\
\hline & & 127 & 265 & 200 & 80 & 15 & 7266 \\
\hline & & 141 & 266 & 189 & 74 & 10 & 69 \\
\hline & & 151 & 276 & 241 & 85 & 13 & 5035 \\
\hline & & 168 & 286 & 257 & 81 & 16 & 5005 \\
\hline
\end{tabular}




\section{Martin et al.}

during each sampling event; i.e. we attempted to scan a general vicinity every $4 \mathrm{~h}$ within a 12 -h sampling period.

Geographical coordinates were recorded with a Garmin eTrex GPS unit at each fish location. Coordinates were recorded in NAD83 UTM Zone 14N. Locations were mapped using ArcMap version 9.3 (ESRI 2008) and compared to bathymetric maps of the reservoirs created with data from the Lake Mapping Program of the Nebraska Game and Parks Commission.

Twenty-seven white bass were located a minimum of five times (range 5-25 locations per fish) during spring of $2007(N=12)$ and $2008(N=15$; Table 1$)$. White bass with less than five locations were not included in analyses because at least five locations are needed to calculate a home range. Multiple locations of individual fish within a sampling period were separated by at least $3 \mathrm{~h}$. Of those 27 white bass, 16 were in Enders Reservoir and 11 were in Hugh Butler Lake.

We calculated home ranges using a linear method in ArcGIS to allow for comparison among individual white bass movements. The linear method defines a home range as the minimum distance between the two most extreme locations (Hayne 1949) and tends to underestimate home-range size by limiting the home range to one dimension. This distance was calculated manually in ArcGIS by measuring the shortest distance required to travel between the two most extreme locations while staying within the reservoir (i.e. not crossing onto shore).

Other home-range methods, such as the adaptive kernel method, tend to overestimate home-range size when the number of locations is less than 25 (Schoener 1981; Worton 1987) and researchers may introduce bias when reducing a kernel-based home range to the actual available home range within a water body. Like the minimum convex polygon estimator, the linear method is prone to effects of sample size (Burgman \& Fox 2003). However, the dimension issue is likely minimised in fishery studies because most systems are longer in one dimension (e.g. river channels and dendritic reservoirs) than the other.

\section{Results}

\section{Enders Reservoir}

Six white bass had small $(<1000 \mathrm{~m})$ home ranges in Enders Reservoir during spring 2007 and spring 2008. Fish \#51 had the smallest spring home range at Enders Reservoir, which was characterised by a flat, shallow area (Fig. 1). Fish \#157 had a small spring home range located along a steep area of natural rock on the west shoreline of the lower reservoir (Fig. 1). Fish \#129 and \#140 had overlapping spring home ranges restricted to a steep area of natural rock at the northern extent of the riprap dam (Fig. 1). The spring home range of fish \#166 was located in the middle reservoir along a shallow, relatively flat area with inundated trees along the shoreline (Fig. 1). Fish \#115 also had a small spring home range that was restricted to an area with two riprap jetties along the eastern shore (Fig. 1).

Eight white bass had medium (between 1000 and $3000 \mathrm{~m}$ ) spring home ranges that extended across larger portions of Enders Reservoir. Fish \#47 had a spring home range that extended across the centre of the lower reservoir characterised by a relatively deep basin with steep shorelines (Fig. 1). Fish \#58, \#67 and \#68 had spring home ranges located across the middle portion of the reservoir characterised by a shallow flat area with shorelines dominated by small woody trees with the addition of some sandy beaches along the southern shoreline (Fig. 1). Fish \#125 had a spring home range extending across the upper half of the reservoir with locations centred on the sandy point in
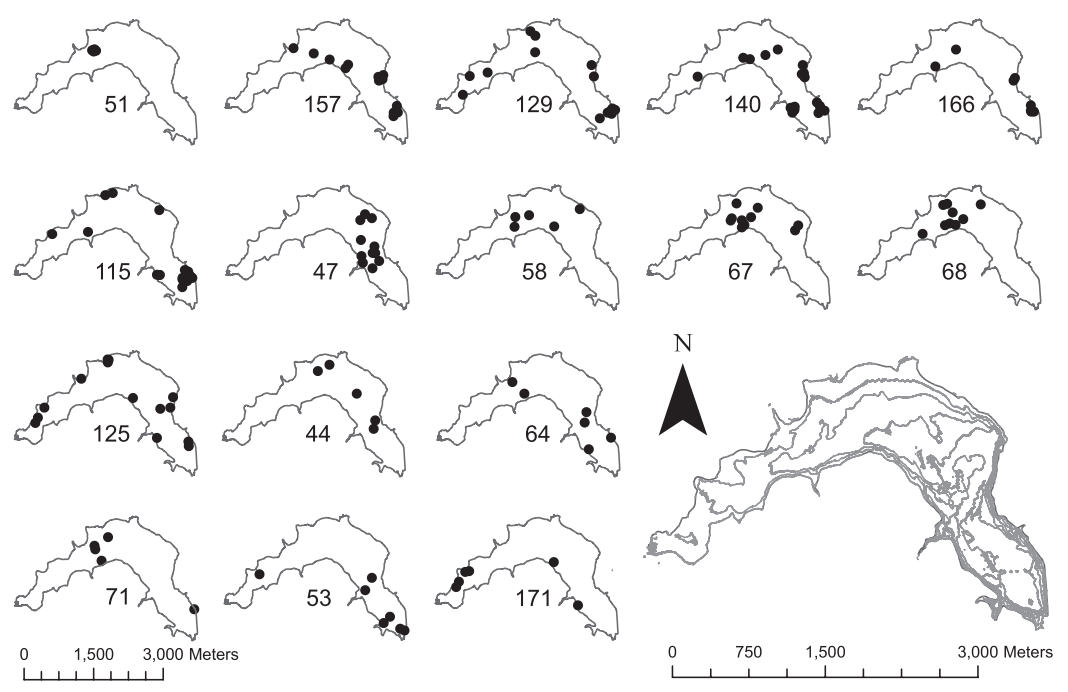

Fig. 1. Locations of tagged white bass with more than five locations in Enders Reservoir, Nebraska, from March to May 2007 (two-digit fish numbers) and March to May 2008 (three-digit fish numbers). Bathymetric map of Enders Reservoir with $2 \mathrm{~m}$ contours included. 
Fig. 2. Locations of tagged white bass with more than five locations in Hugh Butler Lake, Nebraska from March to May 2007 (two-digit fish numbers) and March to May 2008 (three-digit fish numbers). Bathymetric map of Hugh Butler Lake with $2 \mathrm{~m}$ contours included.

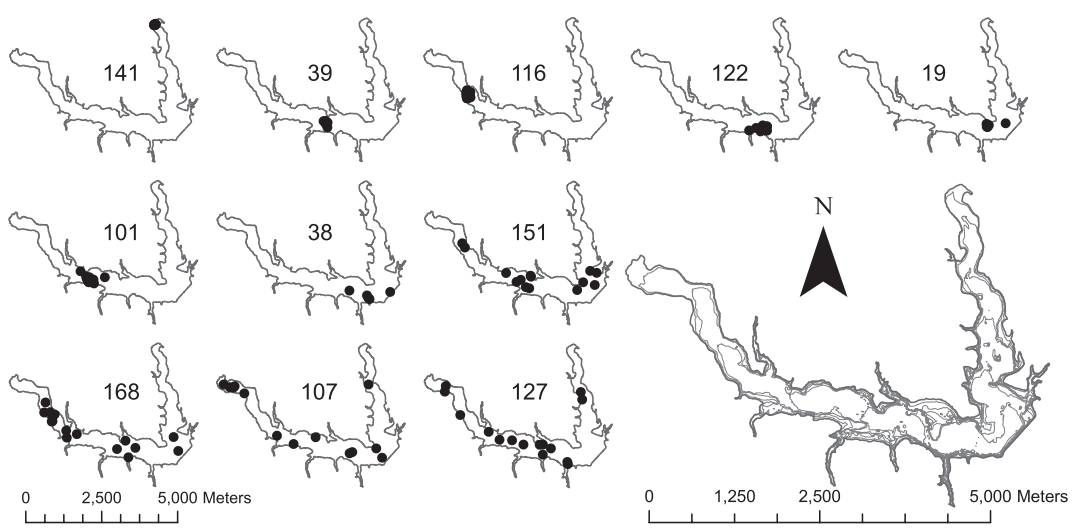

the middle of the reservoir (Fig. 1), whereas the spring home range of \#44 encompassed most of the lower, deeper half of the reservoir (Fig. 1). Fish \#64 and \#71 had locations and spring home ranges that included shallow water of the upper reservoir.

The remaining two white bass had large $(>3000 \mathrm{~m})$ spring home ranges that extended throughout Enders Reservoir. Fish \#53 was found throughout the reservoir during spring and had a linear home range encompassing most of the reservoir (Fig. 1). Fish \#171 also had a large home range extending across most of the reservoir (Fig. 1).

\section{Hugh Butler Lake}

Six white bass had small home ranges in Hugh Butler Lake during spring 2007 and spring 2008. Fish \#141 had the smallest spring home range in Hugh Butler Lake, which was characterised by a local structure of dead, standing trees along an old creek channel in the north arm (Fig. 2). Fish \#39 had a spring home range restricted to a relatively flat area adjacent to a point extending into the west arm (Fig. 2). Fish \#116 had a spring home range located in the upper section of the west arm with most locations occurring along a steep break near shore (Fig. 2). The spring home range of \#122 was centred on a large underwater point extending across the middle of the reservoir with some locations nearby along the southern shore (Fig. 2). Fish \#19 had a small spring home range characterised by locations on either side of a point extending into the lower reservoir (Fig. 2). Fish \#101 had a similar spring home range located along a submerged point further west (Fig. 2).

One white bass had a medium home range in Huge Butler Lake. Fish \#38 had a spring home range in the lower reservoir (Fig. 2). Locations of fish \#38 were mostly along drop-offs (Fig. 2).

The remaining four white bass had large spring home ranges extending throughout Hugh Butler Lake. Fish \#151 and \#168 had locations throughout the west

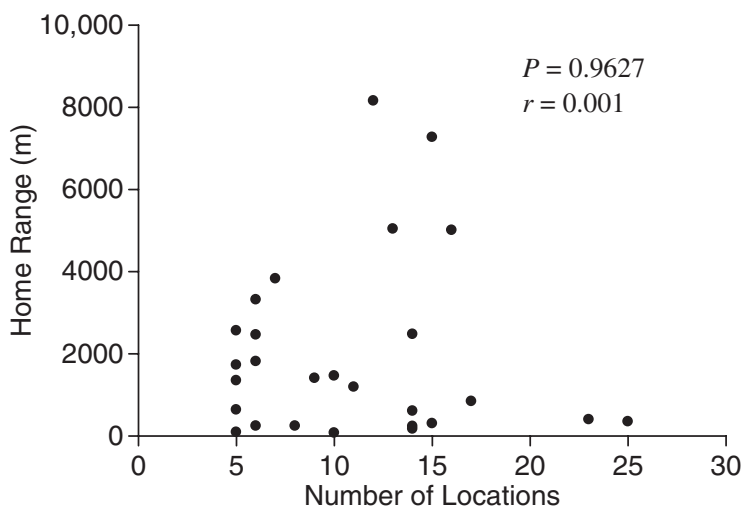

Fig. 3. Correlation of linear home range with the number of locations per individual white bass tracked during spring 2007 and spring 2008 at Enders Reservoir and Hugh Butler Lake, Nebraska.

arm and their spring home ranges encompassed large areas of this arm (Fig. 2). Fish \#107 and \#127 both had locations and spring home ranges extending across the entire reservoir (Fig. 2).

\section{Home-range analysis}

Linear home-range estimates ranged from 69 to $8154 \mathrm{~m}$, with a mean $\pm \mathrm{SE}$ of $1968 \pm 421 \mathrm{~m}$ (Table 1). Home-range size did not differ between years (Kruskal-Wallis test, $\chi^{2}=0.18, P=0.67$ ) or reservoirs $\left(\chi^{2}=0.10, P=0.75\right)$; thus, observations were pooled for further analysis. Twelve white bass had home ranges restricted to small areas of the reservoir $(<25 \%)$, nine white bass had home ranges encompassing $25-75 \%$ of the reservoir and six white bass had home ranges encompassing almost the entire reservoir. Linear home range was not correlated with number of locations per fish $(r=0.001, P=0.96$; Fig. 3). Linear home range was also not correlated with fish total length $(r=-0.23, P=0.25)$, weight $(r=-0.17, \quad P=0.42) \quad$ or condition $\quad(r=0.10$, $P=0.65)$ at the time of tag implantation (i.e. autumn). No evidence of fish shoaling was observed among 


\section{Martin et al.}

tagged fish during tracking (i.e. no more than one fish was observed in the same location at the same time).

\section{Discussion}

The identification of home ranges of white bass during spring (mid-March to May) provides insights into their basic biology. Spawning was limited to approximately 10 days in early May of each year. Thus, linear home ranges described herein encompassed prespawn, spawn and postspawn periods for white bass in these two reservoirs.

Our method of tracking fish using mobile acoustic telemetry should bias the number of encounters towards fish with smaller home ranges. Fish that moved shorter distances were more likely to be encountered during a circuit than fish that moved longer distances. However, no relationship existed between the number of encounters and linear homerange size. Thus, we believe this bias was minimal.

The discontinuity in size of white bass home ranges suggests that two distinct behaviours of white bass occur in these reservoirs during spring. One behaviour produces movement during spring throughout much of the reservoir. The other produces more localised movement - a seemingly counterintuitive result given that white bass is a pelagic species. At least six competing hypotheses for the observed discontinuity in size of spring home ranges can be posed, including: (1) larger fish may require greater home-range areas to obtain sufficient energy for growth and reproduction (Peters 1983; Minns 1995); (2) fish in greater condition (e.g. $W_{\mathrm{r}}$ ) may travel less because they are in an area with abundant resources (optimal foraging theory; MacArthur \& Pianka 1966); (3) male fish may remain close to potential spawning sites throughout the prespawn and spawning periods; (4) older, reproductively senescent fish may travel little because they lack migratory behaviour that is associated with spawning periods; (5) some fish may spawn in intermittent years, and remain in energetically favourable areas during nonspawning years to promote growth (JØrgensen et al. 2006; Secor 2008); and (6) inter-individual variation in standard metabolic rates may be associated with varying levels of aggressiveness and activity levels (Cutts et al. 2002). Hypotheses 1 and 2 were not supported by our results (body size and $W_{\mathrm{r}}$ were not correlated with linear home-range size), though the sample size was limited $(N=27)$. Although hypothesis 2 was not supported by our data, white bass with small home ranges selected for areas characterised by one of two features: underwater drop-offs or relatively flat areas with small trees. These areas may provide abundant food such that time and energy expenditure is minimised during the search phase of foraging.
These areas may also provide habitat necessary for spawning, although results from patch occupancy modelling and acoustic telemetry did not support this contention (Martin 2008). We did not gather age, gender, reproductive status or metabolic data from tagged fish and thus were unable to test hypotheses 3 , 4,5 or 6 . Further research is needed to determine the mechanisms responsible for the discontinuity in white bass spring home-range size.

\section{Acknowledgements}

We thank Chris Lewis and many volunteers for assisting with field work. We also thank Robert Hayward, Craig Paukert and David Willis for helpful comments on earlier drafts of this manuscript. This project was funded by Federal Aid in Sport Fish Restoration; project F-174-R, administered by the Nebraska Game and Parks Commission. The contents of this project are solely the responsibility of the author and do not necessarily represent official views of the Nebraska Game and Parks Commission or the U.S. Geological Survey. Reference to trade names does not imply endorsement by the authors or U.S. government.

\section{References}

Beck, H.D. \& Willis, D.W. 2000. Biotelemetry of white bass in a South Dakota glacial lake. Journal of Freshwater Ecology 15: 229-236.

Brown, M.L. \& Murphy, B.R. 1991. Standard weight $\left(W_{\mathrm{s}}\right)$ development for striped bass, white bass, and hybrid striped bass. North American Journal of Fisheries Management 11: 451-467.

Burgman, M.A. \& Fox, J.C. 2003. Bias in species range estimates from minimum convex polygons: implications for conservation and options for improved planning. Animal Conservation 6: 19-28.

Burt, W.H. 1943. Territoriality and home range: concepts applied to mammals. Journal of Mammalogy 24: 346-352.

Cutts, C.J., Metcalfe, N.B. \& Taylor, A.C. 2002. Juvenile Atlantic salmon (Salmo salar) with relatively high standard metabolic rates have small metabolic scopes. Functional Ecology 16: 73-78.

ESRI. 2008. ArcMap GIS, version 9.1. Redlands, CA: Environmental Systems Research Institute.

Foust, J.C. \& Haynes, J.M. 2007. Failure of walleye recruitment in a lake with little suitable spawning habitat is probably exacerbated by restricted home ranges. Journal of Freshwater Ecology 22: 297-309.

Gerking, S.D. 1959. The restricted movement of fish populations. Biological Reviews 34: 221-242.

Hart, L.G. \& Summerfelt, R.C. 1975. Surgical procedures for implanting ultrasonic transmitters into flathead catfish $(P y$ lodictis olivaris). Transactions of the American Fisheries Society 104: 56-59.

Hayne, D.W. 1949. Calculation of size of home range. Journal of Mammalogy 30: 1-18.

Jackson, J.R. \& Hightower, J.E. 2001. Reservoir striped bass movements and site fidelity in relation to seasonal patterns in 
habitat quality. North American Journal of Fisheries Management 21: 34-45.

JØrgensen, C., Ernande, B., Fiksen, Ø. \& Dieckmann, U. 2006. The logic of skipped spawning in fish. Canadian Journal of Fisheries and Aquatic Sciences 63: 201-211.

MacArthur, R.H. \& Pianka, E.R. 1966. On the optimal use of a patchy environment. The American Naturalist 100: 603-609.

Martin, D.R. 2008. Habitat selection by spawning walleye and white bass in irrigation reservoirs of the Republican River Basin, Nebraska. Master's thesis. Lincoln, NE: University of Nebraska. 263 pp.

Minns, C.K. 1995. Allometry of home range size in lake and river fishes. Canadian Journal of Fisheries and Aquatic Sciences 52: 1499-1508.

Ng, C.L., Able, K.W. \& Grothues, T.M. 2007. Habitat use, site fidelity, and movement of adult striped bass in a southern New Jersey estuary based on mobile acoustic telemetry. Transactions of the American Fisheries Society 136: 13441355.

Paukert, C.P., Willis, D.W. \& Bouchard, M.A. 2004. Movement, home range, and site fidelity of bluegills in a Great Plains lake. North American Journal of Fisheries Management 24: 154-161.

Peters, R.H. 1983. The ecological implications of body size. Cambridge: Cambridge University Press, 329 pp.

Schoener, T.W. 1981. An empirically based estimate of home range. Theoretical Population Biology 20: 281-325.
Scott, W.B. \& Crossman, E.J. 1973. Freshwater fishes of Canada. Bulletin 184. Ottawa, ON: Fisheries Research Board of Canada.

Secor, D.H. 2008. Influence of skipped spawning and misspecified reproductive schedules on biological reference points in sustainable fisheries. Transactions of the American Fisheries Society 137: 782-789.

Vokoun, J.C. 2003. Kernel density estimates of linear home ranges for stream fishes: advantages and data requirements. North American Journal of Fisheries Management 23: 1020 1029.

Wege, G.J. \& Anderson, R.O. 1978. Relative weight $\left(W_{\mathrm{r}}\right)$ : a new index of condition for largemouth bass. In: Novinger, G.D. \& Dillard, J.G., eds. New approaches to management of small impoundments. North Central Division, Special Publication Number 5. Bethesda, MD: American Fisheries Society, pp. 79-91.

Weller, R.R. \& Winter, J.D. 2001. Seasonal variation in home range size and habitat use of flathead catfish in Buffalo Springs Lake, Texas. North American Journal of Fisheries Management 21: 792-800.

Winter, J.D. 1977. Summer home range movements and habitat use by four largemouth bass in Mary Lake, Minnesota. Transactions of the American Fisheries Society 106: 323330 .

Worton, B.J. 1987. A review of models of home range for animal movement. Ecological Modeling 38: 277-298. 